\title{
White Button Mushroom Extract
}

National Cancer Institute

\section{Source}

National Cancer Institute. White Button Mushroom Extract. NCI Thesaurus. Code C78490.

\begin{abstract}
A heat-stable extract of white button mushrooms (Agaricus bisporus) with potential chemopreventive and immunomodulating activities. Phytochemicals, such as polysaccharides and especially beta-D-glucans found in the white button mushroom extract, bind to and inhibit the activity of aromatase, an enzyme responsible for the conversion of androgens to estrogens and which is often upregulated in breast cancer cells. The consequent decrease in estrogen production may result in the suppression of estrogen-dependent cellular proliferation. In addition, this extract may promote dendritic cell (DC) maturation, increase interferon gamma (IFN-gamma) and tumor necrosis factor alpha (TNF-alpha) production, and may enhance natural killer (NK) cell activity, thus amplifying both innate and T cell-mediated immune responses against cancer cells.
\end{abstract}

